\title{
Pengembangan Perangkat Pembelajaran Menggunakan Model Discovery Learning Berbasis Pembelajaran Matematika Realistik pada Materi Garis Singgung Lingkaran Kelas VIII SMP/MTs
}

\author{
Parsaoran Selpanri Sitorus ${ }^{1}$, Nahor Murani Hutapea ${ }^{2}$, Rini Dian Anggraini ${ }^{3}$ \\ 1, 2,3 Program Studi Pendidikan Matematika, Fakultas Keguruan dan Ilmu Pendidikan, Universitas Riau, \\ Jl. Bina Widya Simpang Baru, Pekanbaru, Indonesia \\ nahorm.hutapea@lecturer.unri.ac.id
}

\begin{abstract}
This research was development research with the aim of producing a learning device accordance with the 2013 curriculum. The learning devices of this research were syllabus, lesson plan, and student's activity sheet. The development model that used in this study was the ADDIE model, namely analysis, design, development, implementation, and evaluation. The data were collected using validation techniques and student's response questionnaires. The devices that had been developed were then validated by three validators. After the validations average result are analyzed, the average is obtained the syllabus 3.70 which is in a very valid category, the lesson plan is 3.84 which is in a very valid category, and the student's activity sheet is 3.85 which is in a very valid category. Furthermore, student's activity sheet was tested, and the result of the trial is 84.70 which is in a very practical category. The conclusion from the results of the analysis is that the development of learning devices based on realistic mathematics education on the material of tangent to a circle for grade VIII SMP/MTs meets the valid and practical requirements to be used in SMP/MTs.
\end{abstract}

Keywords: Learning Device, Discovery Learning Model, Realistic Mathematics Education, Tangent to A Circle.

\begin{abstract}
Abstrak
Penelitian ini adalah penelitian pengembangan dengan tujuan menghasilkan suatu perangkat pembelajaran yang sejalan dengan kurikulum 2013. Perangkat pembelajaran yang dimaksud dalam penelitian ini berupa Silabus, Rencana Pelaksanaan Pembelajaran (RPP), dan Lembar Aktivitas Siswa (LAS). Model pegembangan yang digunakan adalah model ADDIE, yaitu analysis, design, development, implementation, dan evaluation. Pengumpulan data menggunakan teknik validasi dan angket respon siswa. Perangkat yang telah dikembangkan kemudian divalidasi oleh tiga orang validator. Setelah hasil validasi dianalisis diperoleh rata-rata penilaian: (1) Silabus sebesar 3.70 dengan kategori sangat valid; (2) RPP sebesar 3.84 dengan kategori sangat valid; (3) dan LAS sebesar 3.85 dengan kategori sangat valid. Selanjunya LAS diujicobakan pada enam siswa kelas IX SMP Negeri 42 Pekanbaru dengan hasil ujicoba adalah 84.70 dengan kategori sangat praktis. Dari hasil analisis diperoleh bahwa pengembangan perangkat pembelajaran model Discovery Learning berbasis Pembelajaran Matematika Realistik pada materi Garis Singgung Lingkaran kelas VIII SMP/MTs memenuhi syarat valid dan praktis untuk digunakan di SMP/MTs.
\end{abstract}

Kata kunci: Perangkat Pembelajaran, Model Discovery Learning, Pembelajaran Matematika Realistik, Garis Singgung Lingkaran.

Copyright (c) 2021 Parsaoran Selpanri Sitorus, Nahor Murani Hutapea, Rini Dian Anggraini

$\triangle$ Corresponding author: Nahor Murani Hutapea

Email Address: nahorm.hutapea@ lecturer.unri.ac.id ((Jl. Bina Widya Simpang Baru, Pekanbaru)

Received 21 July 2021, Accepted 15 August 2021, Published 29 September 2021

\section{PENDAHULUAN}

Proses pembelajaran di sekolah dasar hingga sekolah menengah sampai saat ini menggunakan kurikulum 2013 dengan pendekatan saintifik. Kurikulum 2013 menjadikan guru sebagai fasilitator untuk mengarahkan siswa dan bertujuan agar siswa aktif dalam proses pembelajaran. Guru sebagai fasilitator harus merencanakan proses pembelajaran, baik dari segi model pembelajaran maupun metode pembelajaran untuk memudahkan siswa dalam proses pembelajaran. Perencanaan ini dimulai dari pembuatan kelengkapan perangkat pembelajaran yang mencakup Silabus, Rencana Pelaksanaan Pembelajaran (RPP), serta Lembar Aktivitas Siswa (LAS) sebagai bahan yang digunakan guru dalam 
proses pembelajaran. Silabus adalah pedoman menyusun kerangka pembelajaran untuk satu Kompetensi Dasar. RPP adalah rencana kegiatan yang menggambarkan prosedur dan pengorganisasian pembelajaran untuk mencapai satu kempetensi yang ditetapkan dalam standar kompetensi dan telah dijabarkan dalam silabus. LAS adalah lembaran-lembaran yang berisi tugas yang harus dikerjakan siswa sehingga dapat menemukan konsep didalamnya. LAS memuat sekumpulan kegiatan mendasar yang harus dilakukan siswa untuk memaksimalkan pemahamannya dalam upaya pembentukan kompetensi dasar sesuai indikator pencapaian hasil belajar yang harus ditempuh.

Permendikbud No 22 Tahun 2016 menyatakan bahwa guru berkewajiban menyusun perangkat pembelajaran berupa Silabus dan RPP secara lengkap dan sistematis, agar pembelajaran berlangsung secara interaktif, inspiratif, menyenangkan, manantang, efisien, memotivasi siswa untuk berpartisipasi aktif dalam proses pembelajaran. LAS dipersiapkan guru untuk menunjang Kurikulum 2013 agar pembelajaran berpusat pada siswa. Hal tersebut dimaksudkan agar tujuan pembelajaran kurikulum 2013 tercapai (Permendikbud Nomor 58 Tahun 2014). (Yustianingsih et al., 2017) mengatakan bahwa perangkat pembelajaran yang dibuat guru belum membantu siswa mengkontruksikan pengetahuan yang dimiliki dalam menyelesaikan masalah, sebagai upaya untuk mencapai tujuan pembelajaran. Sejalan dengan yang disampaikan (Khomsiatun \& Retnawati, 2015) mengatakan bahwa guru jarang melakukan pembelajaran dengan LAS karena guru kesulitan dalam membuat LAS. Menurut penelitian (Ariawan \& Putri, 2020) RPP disusun guru sudah berdasarkan kurikulum 2013, namun langkah-langkah metode pembelajaran yang digunakan belum jelas, satu RPP digunakan untuk beberapa pertemuan, dan siswa menggunakan LAS dari penerbit tertentu yang dibeli dari sekolah sehingga pembelajaran menjadi pasif karena LAS tersebut hanya berisikan rumus-rumus dan soal-soal yang harus dikerjakan siswa. Perangkat pembelajaran dimaksudkan untuk memudahkan guru dalam proses pembelajaran serta memberikan pemahaman konsep dengan baik kepada siswa. Tiga aspek penting yang harus diperhatikan dalam kurukulum 2013 yaitu aspek afektif, aspek psikomotor, dan aspek kognitif. Komponen yang wajib ada dalam kurikulum 2013 adalah (1) kegiatan mengamati; (2) kegiatan menanya; (3) kegiatan manalar; (4) kegiatan mencoba; dan (5) kegiatan membentuk jejaring (Sinambela, 2017).

Berdasarkan permasalahan di atas tentang perangkat pembelajaran yang belum sesuai dengan kurikulum 2013. Peneliti juga melakukan observasi dan wawancara dengan guru matematika SMP Negeri 42 Pekanbaru dan SMP Muhammadiyah 4 Pekanbaru, untuk melihat fakta perangkat perangkat pembelajaran yang digunakan guru. Hasil observasi pembelajaran matematika diperoleh bahwa Silabus yang dibuat oleh guru masih kurang dari segi komponen maupun model pembelajaran. Komponen yang belum tercantum pada Silabus yang dibuat oleh guru yaitu, Indikator Pencapaian Kompetensi (IPK), penilaian, sumber belajar, dan model pembelajaran pada kegiatan pembelajaran. Silabus yang dibuat guru masih belum mengacu pada model pembelajaran yang sesuai dengan kurikulum 2013 pada aspek kegiatan pembelajaran, karena hanya berisi kegiatan yang dilakukan siswa saja. IPK dari Kompetensi Dasar (KD) yang direncanakan belum dijabarkan, sehingga tidak dapat menunjukkan apa saja yang harus dicapai siswa dari setiap kegiatan pembelajaran. Kelemahan yang telah dipaparkan diatas 
Pengembangan Perangkat Pembelajaran Menggunakan Model Discovery Learning Berbasis Pembelajaran Matematika Realistik pada Materi Garis Singgung Lingkaran Kelas VIII SMP/MTs, Parsaoran Selpanri Sitorus, Nahor Murani Hutapea, Rini Dian Anggraini

menunjukkan bahwa Silabus yang dibuat guru belum menunjukkan perangkat pembelajaran sesuai dengan perangkat pembelajaran yang diharapkan oleh Kurikulum 2013. Berikut Silabus yang dirancang oleh guru.

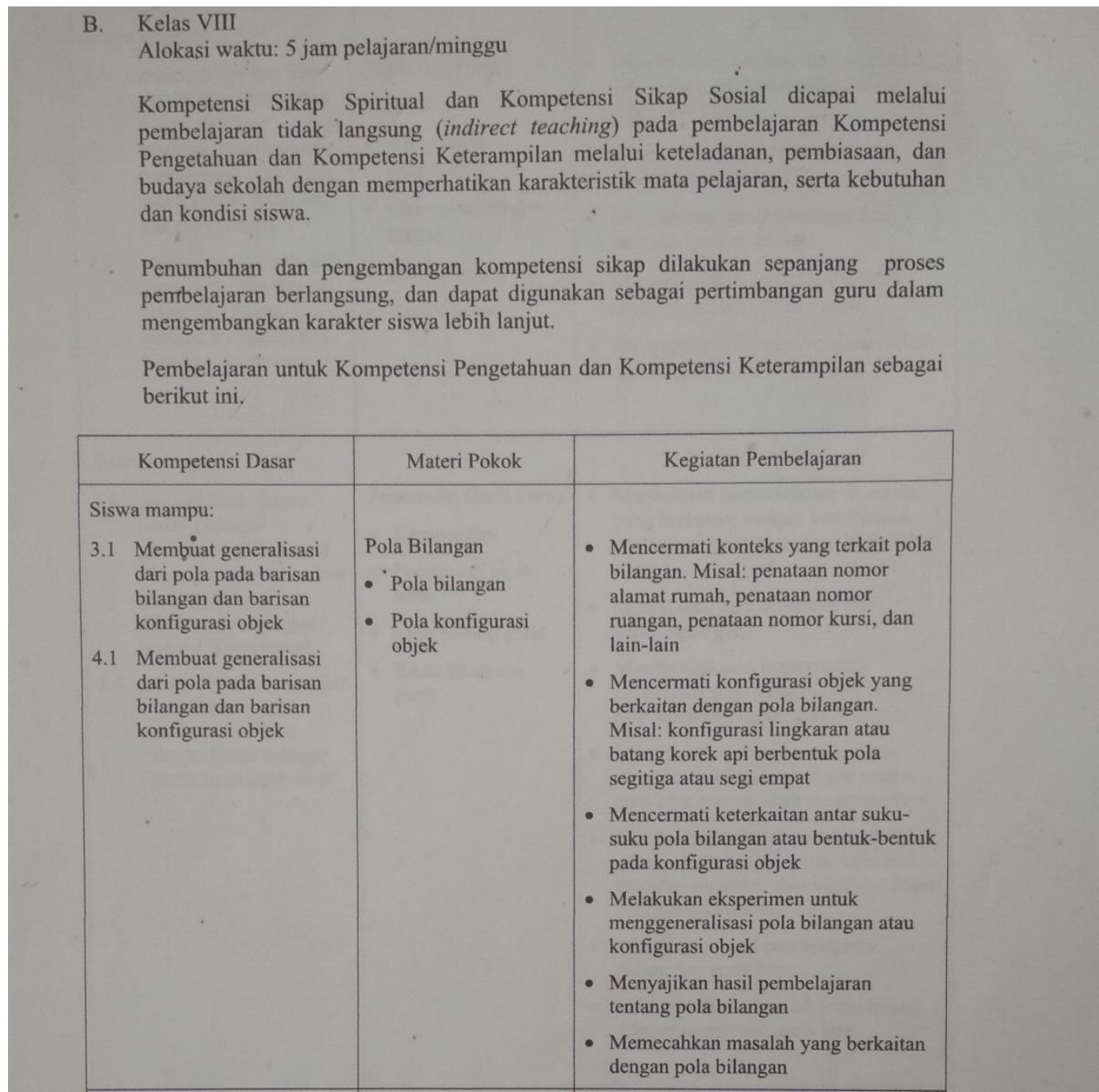

Gambar 1. Silabus yang dirancang oleh Guru

Wawancara yang dilakukan terhadap guru SMP Negeri 42 Pekanbaru diperoleh informasi bahwa guru membuat perangkat pembelajaran hanya sebagai syarat untuk administrasi sekolah saja. Sedangkan guru SMP Muhammadiyah 4 Pekanbaru menjelaskan bahwa guru sesekali melakukan pembelajaran menggunakan perangkat pembelajaran yang dirancang, artiya guru tidak sepenuhnya menggunakan perangkat pembelajaran yang dirancang, sehingga perangkat pembelajaran yang dibuat guru masih perlu diperbaiki. Disamping itu, untuk satu Kompetensi Dasar, guru membuat RPP yang terdiri dari beberapa pertemuan, yang berdampak kepada tujuan pembelajaran yang akan dicapai belum terencana dengan baik. Berikut RPP yang dirancang oleh guru. 


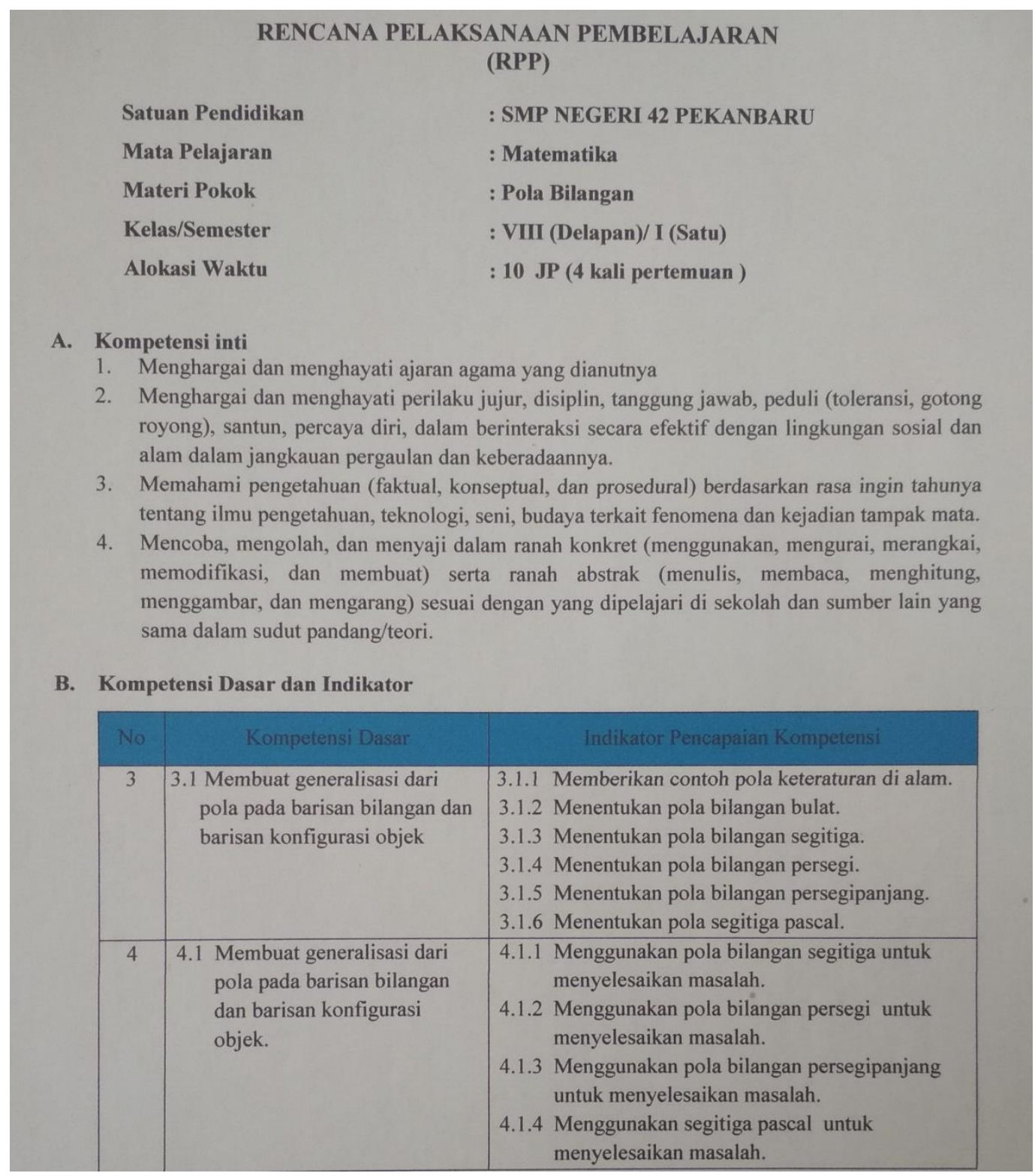

Gambar 2. RPP yang dirancang oleh Guru

LAS yang dibuat guru masih terdapat banyak kekurangan mulai dari tidak adanya sampul LAS, model pembelajaran dalam LAS berbeda dengan yang direncanakan pada RPP dimana tidak terlihat model pembelajaran yang dianjurkan pada Kurikulum 2013. Isi LAS tidak membantu siswa dalam pemecahan masalah maupun memahami konsep, belum terlihat komponen pendekatan saintifik. Guru mengatakan bahwa LAS tersebut hanya sebagai syarat untuk administrasi sekolah saja.

Fakta dilapangan juga terlihat bahwa guru memfasilitasi siswa dengan modul pengayaan yang diterbitkan oleh penerbit tertentu, guru beranggapan bahwa modul tersebut merupakan LAS dan digunakan untuk proses pembelajaran serta pemahaman konsep bagi siswa. Modul tersebut setelah dianalisis hanya berisikan ringkasan materi dan kumpulan soal-soal yang perlu dikerjakan siswa. (Yuliana, 2017) menyatakan bahwa LAS yang berasal dari terbitan tertentu hanya berisi ringkasan materi dan soal-soal sehingga membuat siswa kurang termotivasi untuk aktif dalam proses pembelajaran. Alasan guru tidak menggunakan LAS buatan sendiri beragam, namun dapat disimpulkan 
Pengembangan Perangkat Pembelajaran Menggunakan Model Discovery Learning Berbasis Pembelajaran Matematika Realistik pada Materi Garis Singgung Lingkaran Kelas VIII SMP/MTs, Parsaoran Selpanri Sitorus, Nahor Murani Hutapea, Rini Dian Anggraini

dari alasan yang disampaikan, yaitu guru merasa kesulitan dan kurang paham dalam membuat LAS yang sesuai dengan kurikulum 2013.

Menurut Permendikbud Nomor 22 Tahun 2016, guru berkewajian membuat perangkat pembelajaran berdasarkan materi yang akan diajarkan untuk memudahkan guru dalam proses pembelajaran. Perangkat pembelajaran sebagai panduan atau pemberi arah bagi seorang guru. Hal tersebut penting karena perangkat pembelajaran adalah sesuatu yang sistematis dan terpola. Masih banyak guru yang hilang arah ditengah-tengah proses pembelajaran hanya karena tidak memiliki perangkat pembelajaran. Oleh karena itu, mengembangkan perangkat pembelajaran memberi panduan terkait menyiapkan dan memberikan panduan untuk merancang perangkat pembelajaran yang lebih baik. Dengan kata lain bahwa perangkat pemebelajaran tidak hanya sebagai kelengkapan administrasi, tetapi sebagai media meningkatkan profesionalisme.

Pengembangan perangkat perlu memperhatikan pendekatan pembelajaran dan model/metode pembelajaran yang sesuai agar dapat tercapainya tujuan pembelajaran sesuai yang diharapkan. Discovery Learning (pembelajaran berbasis penemuan) merupakan model pembelajaran yang disarankan pada Kurikulum 2013 dan sejalan dengan pendekatan saintifik agar siswa dapat menemukan dan memahami konsep secara mandiri dengan bantuan terbatas oleh guru. Discovery Learning masih belum memberikan pengalaman dan pemahaman yang baik bagi siswa dalam menemukan rumus matematika. Dengan menambahkan pendekatan Pembelajaran Matematika Realistik pada proses pembelajaran Discovery Learning, siswa akan dibimbing untuk mengkonstruksikan penemuan rumus kepada siswa. Discovery Learning berbasis pembelajaran realistik akan lebih bermakna bagi siswa. Pembelajaran Matematika Realistik (PMR) atau Realistic Mathematics Education (RME) merupakan pendekatan matematika yang menggunakan penerapan matematika untuk mengorganisasikan dan menyelesaikan masalah yang ada pada situasi nyata (Aris Shoimin, 2014). Masalah realistik tidak harus berupa masalah sehari-hari, tapi masalah realistik juga merupakan masalah yang dapat dibayangkan atau nyata dalam pikiran siswa (Wijaya, 2012). (Hadi, 2017) mengungkapkan bahwa pendekatan PMR mengubah pembelajaran dari abstrak menjadi realistik dan kontekstual bagi siswa. Penemuan konsep dengan masalah realistik akan lebih mudah diterima siswa dengan penalaran dan akan mudah dalam penemuan konsep dalam proses pembelajaran.

(Nazarudin, 2007) menjelaskan yaitu perangkat pembelajaran adalah persiapan pelaksanaan dan evaluasi pembelajaran yang disusun oleh guru agar pembelajaran dapat dilakukan secara sistematis dan memperoleh hasil yang diharapkan. (Trianto, 2009) menyatakan bahwa perangkat pembelajaran matematika adalah perangkat yang diperlukan dan dipergunakan dalam mengelola proses pembelajaran matematika. Pendapat para ahli tentang perangkat pembelajaran dapat disimpulkan bahwa perangkat pembelajaran adalah bahan, alat, media, petunjuk dan pedoman yang disusun secara sistematis oleh guru agar proses pembelajaran yang dilakukan dapat memperoleh hasil yang diharapkan.

Salah satu materi yang cocok dengan model Discovery Learning berbasis PMR adalah materi Garis Singgung Lingkaran, karena dalam proses pembelajaran perlu mengaitkan materi sebelumnya 
untuk menemukan konsep Garis Singgung Lingkaran dengan permasalahan yang bisa dibayangkan oleh siswa. (Efrida et al., 2012) mengungkapkan bahwa penyajian permasalahan kehidupan sehari-hari membuat siswa akan lebih mudah memahami dan memaknai permasalahan tersebut. Siswa juga lebih terlibat aktif dalam proses pembelajaran dengan permasalahan yang dapat dibayangkan dan proses pembelajaran akan berpusat pada siswa. Sejalan dengan (Indira et al., 2019) menyatakan bahwa pembelajaran dengan Discovery Learning pada materi Garis Singgung Lingkaran membuat siswa aktif dalam proses pembelajaran sehingga materi yang diajarkan lebih mudah diingat oleh siswa karena menemukan konsep secara mandiri.

Sesuai dengan yang disajikan dalam latar belakang, peneliti tertarik mengembangkan perangkat pembelajaran kurikulum 2013 yang terdiri dari Silabus, RPP, dan LAS melalui penerapan Discovery Learning berbasis Pembelajaran Matematika Realistik yang memenuhi aspek valid dan praktis pada materi Garis Singgung Lingkaran.

\section{METODE}

Model dalam mengembangkan perangkat pembelajaran ini adalah model ADDIE. Model ini dipilih karena model ini sederhana dan sistematik sehingga sangat sesuai dengan karakteristik pengembangan perangkat pembelajaran. ADDIE dikembangkan oleh Dick \&Carry pada tahun 1996. (Mulyatiningsih, 2012) menjelaskan bahwa langkah-langkah pengembangan produk pada model ADDIE adalah Analysis, Design, Development, Implementation, dan Evaluation.

Analisis merupakan tahap pertama dalam model pengembangan ADDIE. Menurut (Pribadi, 2009) analisis terdiri atas dua tahapan, yaitu analisis kinerja atau performance analysis dan analisis kebutuhan atau need analysis. Analisis kinerja dilakukan untuk untuk mengetahui dan mengklasifikasi apakah masalah kinerja yang dihadapi memerlukan solusi berupa program penyelenggaraan pembelajaran atau perbaikan manajemen. Pada tahap ini peneliti menganalisis kelayakan untuk syaratsyarat pengembangan. Analisis kurikulum, analisis materi dan analisis karakteristik siswa merupakan cakupan aktivitas yang dilakukan peneliti dalam tahapan analisis. Analisis kurikulum yang dilakukan yaitu standar isi dan standar kompetensi lulusan sesuai dengan indikator-indikator yang telah dirumuskan. Analisis materi yaitu menentukan materi dalam KD pada kurikulum 2013, kemudian membaginya kedalam beberapa sub bagian untuk perumusan konsep dalam pembelajaran sesuai dengan cakupan IPK. Analisis karakteristik terdiri atas indentifikasi yang berkaitan dengan siswa, diantaranya adalah rentang usia, jenis kelamin, level pendidikan, tingkat sosial ekonomi, latar belakang, gaya belajar, pengalaman, dan sikap.

Langkah kedua dalam model pengembangan ADDIE adalah design atau perancangan. Pengumpulan referensi merupakan kegiatan yang dilakukan oleh peneliti pada tahap perancangan yang kemudian dijadikan acuan dalam mengembangkan perangkat pembelajaran. Kemudian menyusun rancangan atau kerangka Silabus, RPP, dan LAS, merancang lembar validasi perangkat pembelajaran 
Pengembangan Perangkat Pembelajaran Menggunakan Model Discovery Learning Berbasis Pembelajaran Matematika Realistik pada Materi Garis Singgung Lingkaran Kelas VIII SMP/MTs, Parsaoran Selpanri Sitorus, Nahor Murani Hutapea, Rini Dian Anggraini

untuk validator, dan merancang lembar angket respon siswa terhadap keterlaksanaan (praktikalitas) LAS kelas VIII SMP/MTs pada materi Garis Singgung Lingkaran.

Development merupakan tahap selanjutnya dari proses pengembangan dan berisi kegiatan realisasi dari tahap design atau tahap sebelumnya. Tindak lanjutan dari tahap pengembangan adalah tahap realisasi produk. Setelah Silabus, RPP, dan LAS dirancang kemudian dikonsultasikan dengan dosen pembimbing. Setelah Silabus, RPP, dan LAS dikonsultasikan kemudian dilakukan validasi oleh ahli yaitu dosen pendidikan matematika hingga dinyatakan valid. Validator menggunakan lembar validasi yang sudah disusun untuk keperluan proses validasi pada tahap sebelumnya. Sebelum diujicobakan dalam kegiatan pembelajaran maka dilakukan tahapan validasi untuk mengetahui kelayakan perangkat pembelajaran yang akan digunakan. Masukan dan saran oleh validator akan dijadikan acuan dalam revisi dan perbaikan perangkat pembelajaran yang sudah divalidasi sebelumnya.

Perangkat pembelajaran yaitu LAS kemudian dilakukan ujicobakan pada kelompok kecil untuk melihat praktikalitas (keterlaksanaan) dari LAS yang telah dikembangkan. Penelitian ini hanya dibatasi sampai tahap uji coba kelompok kecil, karena ujicoba kelompok besar tidak bisa dilakukan sehubungan dengan proses pembelajaran yang tidak berlangsung sebagaimana mestinya karena pandemic Covid-19. Subjek uji coba kelompok kecil pada penelitian ini adalah enam siswa kelas IX SMP Negeri 42 Pekanbaru yang dipilih secara acak dengan kemampuan akademis dan jenis kelamin yang heterogen.

Tahap ini, siswa diminta mengerjakan LAS yang telah dikembangkan ditempat masing-masing. Siswa kemudian mengisi angket respon yang bertujuan untuk menilai LAS tersebut. Peneliti selanjutnya memastikan kendala yang dihadapi siswa saat mengerjakan LAS dengan berkomunikasi terhadap guru yang bersangkutan untuk memperoleh data-data yang lebih akurat dan mendalam tentang respon siswa terhadap LAS. Bagan penelitian pengembangan model ADDIE dapat dilihat pada gambar 4.

Data dalam penelitian ini yaitu kualitatif dan kuantitatif. Data kualitatif yaitu mengenai proses pengembangan produk berupa kata-kata, diperoleh pada tahap analysis, design, development yang meliputi data hasil rancangan perangkat pembelajaran, instrumen penilaian perangkat pembelajaran, validasi perangkat pembelajaran, analisis data validasi perangkat pembelajaran, uji coba LAS dan analisis hasil ujicoba LAS. Data kuantitatif pada penelitian ini diperoleh dari data angket penilaian Silabus, RPP, dan LAS oleh 3 dosen pendidikan matematika, serta angket respon siswa terhadap ujicoba yang dilakukan dengan menggunakan LAS.

Penilaian pada lembar validasi dan angket respon menggunakan skala likert. Untuk menghitung hasil analisis data validasi menggunakan rumus sebagai berikut.

$$
M_{v}=\frac{\sum_{i=0}^{n} \bar{V}_{l}}{n}
$$

(diadaptasi dari (Sudijono, 2009)

Keterangan:

$M_{v}$ : rata-rata total validasi

$\bar{V}_{l} \quad$ : rata-rata validator ke-i 
n : banyaknya validator

Kriteria validasi analisis rata-rata yang digunakan dapat dilihat Tabel 1 berikut.

Tabel 1. Kategori Validitas Peragkat Pembelajaran

\begin{tabular}{|c|c|}
\hline Interval & Kategori \\
\hline $3,25 \leq M_{v} \leq 4$ & Sangat valid \\
\hline $2,50 \leq M_{v}<3,25$ & Valid \\
\hline $1,75 \leq M_{v}<2,50$ & Kurang valid \\
\hline $1,00 \leq M_{v}<1,75$ & Tidak valid \\
\hline
\end{tabular}
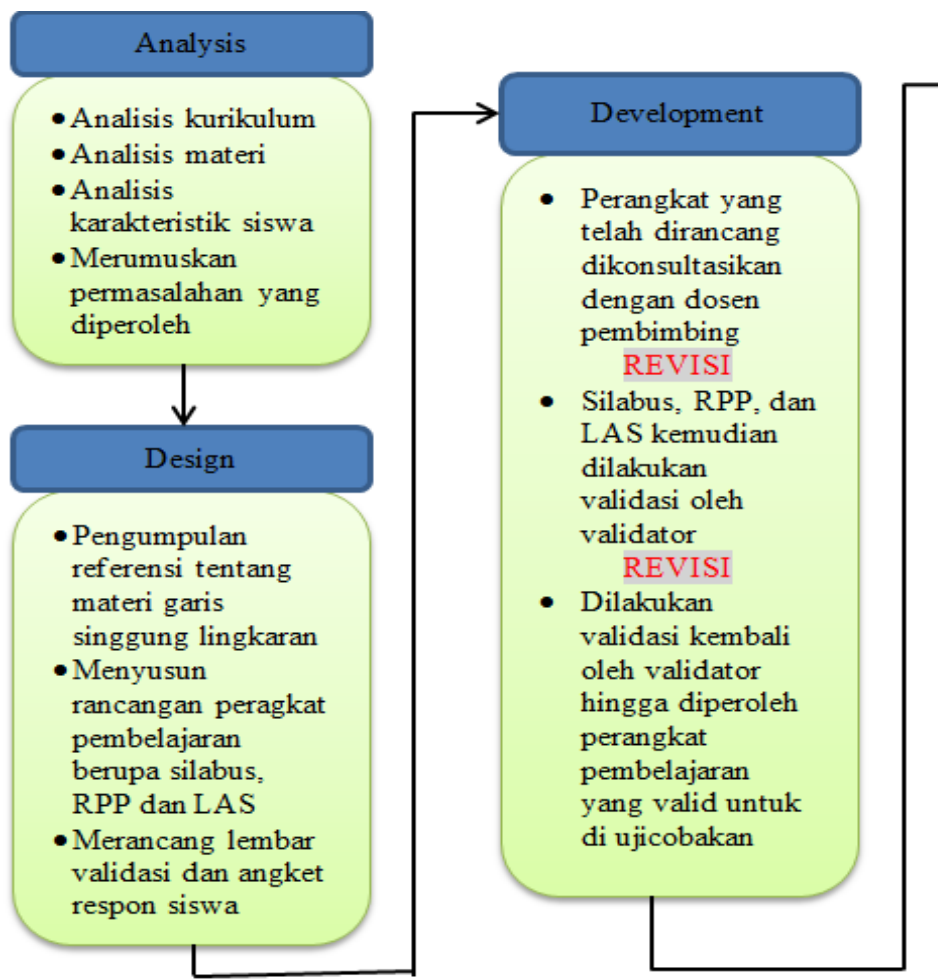

Tahap selajutnya adalah uji coba perangkat pembelajaran pada situasi yang nyata

- Uji coba dilaksanakan hanya pada kelompok kecil, karena ujicoba kelompok besar tidak bisa dilaksanakan

- Memberikan LAS kepada siswa untuk dikerjakan

- Memberikan angket ke siswa untuk melihat ke praktisan perangkat pembelajaran REVISI

-Diperoleh perangkat yang valid dan praktis

Gambar 4. Bagan Penelitian Pengembangan Model ADDIE

Untuk menghitung hasil analisis data hasil uji coba menggunakan rumus sebagai berikut.

$$
V_{p}=\frac{T S a}{T S h} \times 100 \%
$$

Keterangan:

TSa: Total skor empiris dari responden

TSh: Total skor maksimal yang diharapkan

Vp: Skor responden

(Sumber: diadaptasi dari Akbar, 2013)

Pada Tabel 2. merupakan kriteria persentase keterbacaan dan keterlaksanaan LAS yang telah dimodifikasi. 
Pengembangan Perangkat Pembelajaran Menggunakan Model Discovery Learning Berbasis Pembelajaran Matematika Realistik pada Materi Garis Singgung Lingkaran Kelas VIII SMP/MTs, Parsaoran Selpanri Sitorus, Nahor Murani Hutapea, Rini Dian Anggraini

Tabel 2. Kriteria Presentase Keterbacaan dan Keterlaksanaan LAS

\begin{tabular}{|c|c|c|}
\hline No. & Tingkat Pencapaian & Kriteria Keterbacaan \\
\hline 1. & $85,01 \%-100,00 \%$ & Sangat praktis \\
\hline 2. & $70,01 \%-85,00 \%$ & Praktis \\
\hline 3. & $50,01 \%-70,00 \%$ & Kurang praktis \\
\hline 4. & $1,00 \%-50,00 \%$ & Tidak praktis \\
\hline
\end{tabular}

(Akbar, 2013).

\section{HASIL DAN DISKUSI}

Penelitian pengembangan merupakan penelitian yang menghasilkan suatu produk. Produk pada penelitian ini berupa perangkat pembelajaran yaitu Silabus, RPP, dan LAS model Discovery Learning berbasis Pembelajaran Matematika Realistik pada materi Garis Singgung Lingkaran kelas VIII SMP/MTs yang valid dan praktis. Pengembangan perangkat pembelajaran ini melalui beberapa tahapan yaitu analysis (analisis), design (perancangan), dan development (pengembangan).

Pada tahap analysis (analisis), peneliti melakukan beberapa kegiatan yaitu analisis kurikulum, analisis materi, dan analisis karakteristik siswa untuk menyesuaikan kebutuhan perangkat yang akan dikembangan. Dari analisis karakteristik siswa, diperoleh bahwa perangkat pembelajaran yang dikembangkan tidak boleh langsung memberikan masalah abstrak kepada siswa, namun harus diberikan permasalahan yang kongkret menuju ke abstrak. Hal ini dikarenakan karakteristik siswa pada umur tersebut masih kesulitan untuk memahami masalah maupun konsep-konsep abstrak. (Sunarto \& Agung Hartono, 2013) menyatakan bahwa usia remaja 11 tahun masih dalam tahap penyempurnaan penalaran, pengalaman yang kurang membuat siswa kesulitan dalam menangkap dan memahami konsep-konsep yang abstrak, sehingga perlunya penjelasan konkret kepada siswa agar paham akan konsep-konsep yang abstrak tersebut.

Pada tahap design (perancangan), kegiatan yang dilakukan peneliti adalah mengumpulkan referensi tentang Garis Singgung Lingkaran dan merancang Silabus, RPP, dan LAS yang akan dikembangkan. Silabus dan RPP dikembangankan sesuai dengan Permendikbud No. 22 Tahun 2016 menggunakan model Discovery Learning berbasis Pembelajaran Matematika Realistik. LAS yang dikembangkan menggunakan model Discovery Learning berbasis Pembelajaran Matematika Realistik dan memenuhi syarat didaktis, kontruktif, dan teknis. Perangkat pembelajaran model Discovery Learning dengan pendekatan Pembelajaran Matematika Realistik dimaksudkan agar siswa lebih aktuf dalam proses pembelajaran dan dapat mengkonstruksikan konsep secara mandiri dan bantuan terbatas dari guru. Peneliti selanjutnya merancang lembar validitas dan praktikalitas untuk menilai perangkat yang dikembangkan pada tahap perancangan.

Pada tahap development (pengembangan), perangkat pembelajaran yang telah dirancang kemudian direalisasikan atau dikembangkan. Silabus, RPP, dan LAS selanjutnya divalidasi oleh tiga orang dosen Pendidikan Matematika. Setelah perangkat pembelajaran divalidasi, maka perangkat pembelajaran direvisi sesuai dengan saran yang diberikan oleh validator. Penilaian validator terhadap Silabus adalah sangat valid dengan nilai rata-rata 3,70. Jika dikonversikan kedalam persentase, 
kemudian nilai validasi adalah 92,70\%. Penilaian validator terhadap RPP yang dikembangkan adalah 3,84 dengan kategori sangat valid. Jika dikonversikan kedalam persentase, maka nilai validasi adalah 96,16\%. Penilaian validator terhadap LAS adalah 3,85 dengan kriteria sangat valid dan direvisi sesuai saran sebelum diujicoba. Jika dikonversikan kedalam persentase, maka nilai validasi adalah 96,25\%. Berikut gambar perangkat pembelajaran yang dikembangkan peneliti.

\section{SILABUS}

$\begin{array}{ll}\text { Nama Sekolah } & \text { :SMP } \\ \text { Mata Pelajaran } & \text { : Matematika } \\ \text { Kelas/Semester } & \text { : VIII/Genap } \\ \text { Materi Pokok } & : \text { Garis Singgung Lingkaran } \\ \text { Alokasi Waktu } & : 10 \times 40 \text { menit }\end{array}$

KI-1 : Menghargai dan menghayati ajaran agama yang dianutnya.

KI-2 : Menunjukkan perilaku jujur, disiplin, tanggung jawab, peduli (toleransi, gotong royong), santun, dan percaya diri dalam berinteraksi secara efektif sesuai dengan lingkungan, keluarga, sekolah, masyarakat dan lingkungan alam sekitar, bangsa, negara, dan kawasan regional.

KI-3 : Memahami dan menerapkan pengetahuan (faktual, konseptual, prosedural dan metakognitif) berdasarkan rasa ingin tahunya tentang ilmu pengetahuan, teknologi, seni, budaya terkait fenomena dan kejadian tampak mata.

KI-4 : Mengolah, menyaji, dan menalar dalam ranah konkret (menggunakan, mengurai, merangkai, memodifikasi, dan membuat) dan ranah abstrak (menulis, membaca, menghitung, menggambar, dan mengarang) sesuai dengan yang dipelajari di sekolah dan sumber lain yang sama dalam sudut pandang teori.

Gambar 1. Silabus yang Dikembangkan Peneliti

\section{RENCANA PELAKSANAAN PEMBELAJARAN-1 (RPP-1)}

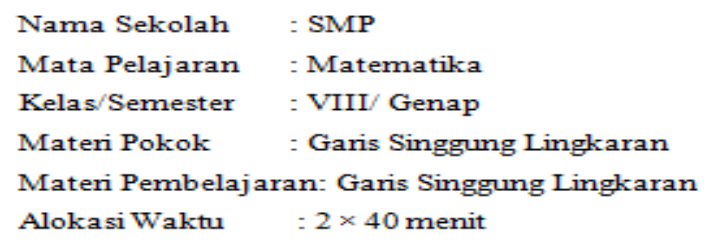

A. Kompetensi Inti

KI. 3 Memahami dan menerapkan pengetahuan (faktual, konseptual dan prosedural berdasarkanrasa ingin tahnorya tentang ilmu pengetahuan. teknologi. seni. budaya terkait fenomena dan keja dian tampak mata.

KI.4 Menuryukkanketerampilan menalar, mengolah, dan menyaji secara: kreatif, produktif, kritis, mandiri, kolaboratif, dan komunikatif, dalam ranah konkret dan ranah abstrak sesuai dengan yang dipelajari di sekolah dan sumber lain yang sama dalam sudut pandang teori.

B. Kompetensi Dasar dan Indikator Pencapaian Kompetensi

B. Kompetensi Dasar dan Indikator Pencapaian Kompetensi
\begin{tabular}{|c|c|}
\hline Kompetensi Dasar (KD) & Indikator Pencapaian Kompetensi \\
\hline $\begin{array}{c}\text { 3.8 Menjelaskan garis singgung } \\
\text { persekutuanluar danpersekrtuan } \\
\text { dalam dua lingkaran dancara } \\
\text { melukisnya. }\end{array}$ & $\begin{array}{c}\text { 3.8.1 Mendefirisikanpengertiandan } \\
\text { sifat-sifat garis singgung } \\
\text { lingkaran }\end{array}$ \\
& $\begin{array}{c}\text { 3.8.2 Menentukan garis singgung } \\
\text { lingkaran } \\
\text { 3.8.3 Menguraikan cara melukis garis } \\
\text { singgung lingkaran }\end{array}$ \\
\hline
\end{tabular}

Gambar 2. RPP yang dikembangkan Peneliti 
Pengembangan Perangkat Pembelajaran Menggunakan Model Discovery Learning Berbasis Pembelajaran Matematika Realistik pada Materi Garis Singgung Lingkaran Kelas VIII SMP/MTs, Parsaoran Selpanri Sitorus, Nahor Murani Hutapea, Rini Dian Anggraini

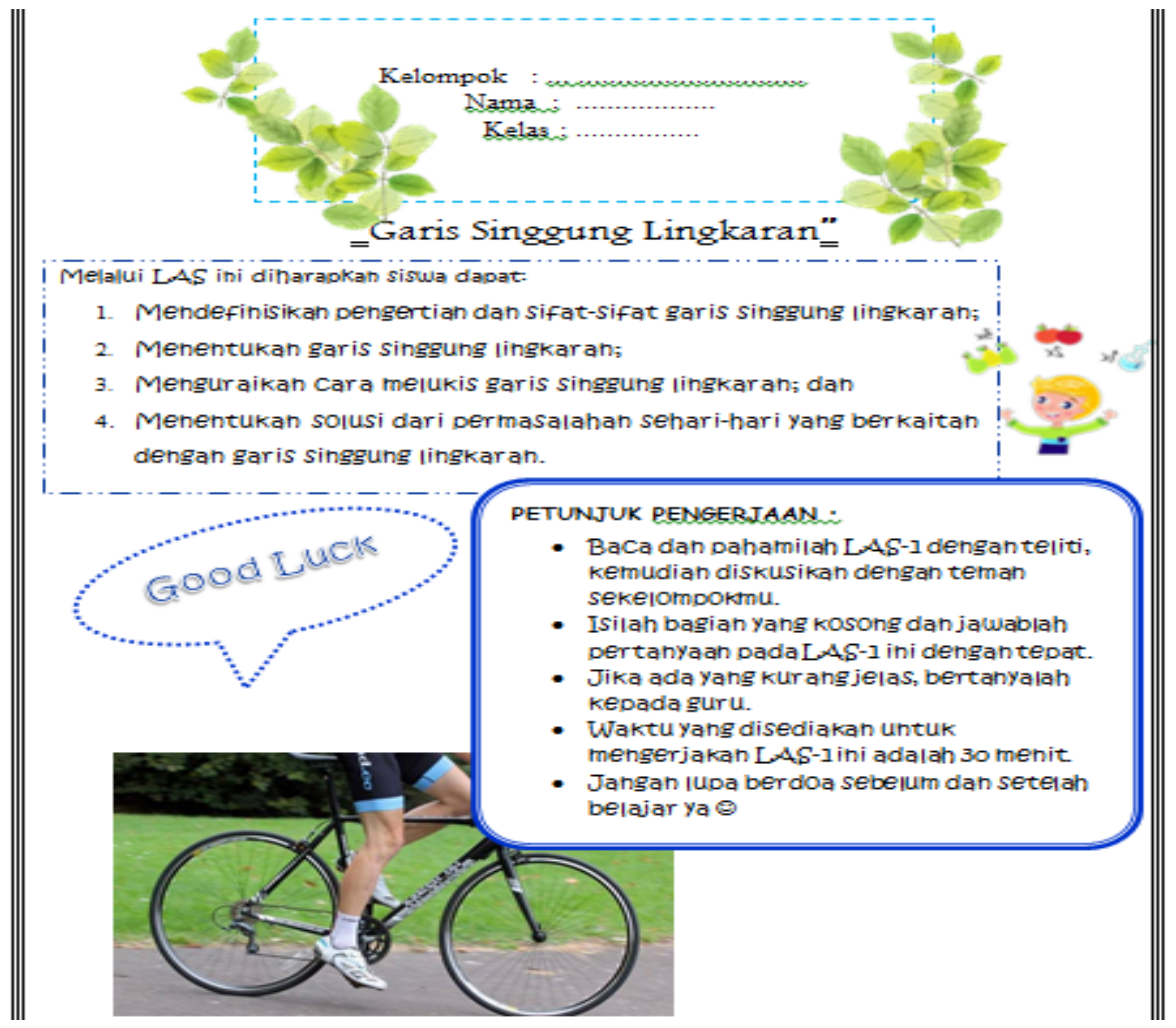

Gambar 3. LAS yang dikembangkan Peneliti

Selanjutya perangkat pembelajaran berupa LAS diujicobakan untuk melihat keterlaksanaan dari LAS yang telah dikembangkan. Uji coba dilakukan pada kelompok kecil, yang berjumlah enam siswa kelas IX SMP Negeri 42 Pekanbaru. Ujicoba dilakukan dengan memberikan LAS kepada siswa melalui guru, guru memilih siswa dengan kemampuan heterogen dan selanjutnya siswa akan mengerjakan LAS. Ujicoba dilakukan ditempat tinggal masing-masing siswa untuk mematuhi protokol kesehatan yang dianjurkan pemerintah. Selanjutnya peneliti berkomunikasi dengan guru mengenai pekerjaan yang siswa lakukan, agar proses ujicoba sesuai dengan arahan yang tertera dilembar LAS. Secara keseluruhan penilaian responden terhadap LAS adalah $84,70 \%$, artinya kriteria LAS adalah praktis. Sesuai dengan kriteria kepraktisan oleh (Akbar, 2013) menyatakan bahwa rentang 70,01\%-85,00\% adalah kategori praktis.

Dari uraian hasil validasi terhadap Silabus, RPP, dan LAS dan hasil angket respon siswa terhadap LAS matematika pada materi Garis Singgung Lingkaran model Discovery Learning berbasis Pembelajaran Matematika Realistik dapat disimpulkan bahwa Silabus, RPP, dan LAS yang dikembangkan adalah valid dan LAS memenuhi syarat praktis untuk digunakan siswa kelas VIII SMP/MTs.

\section{KESIMPULAN}

Berdasarkan hasil analisis dan pembahasan yang telah dipaparkan di atas, diperoleh bahwa pengembangan perangkat pembelajaran menggunakan model Discovery Learning berbasis 
Pembelajaran Matematika Realistik pada materi Garis Singgung Lingkaran kelas VIII SMP/MTs memenuhi syarat valid dan praktis untuk digunakan di SMP/MTs.

\section{UCAPAN TERIMA KASIH}

Peneliti bersyukur kepada Tuhan Yang Maha Esa karena telah memberikan kelancaran dalam penelitian ini. Terimakasih peneliti kepada Bapak/Ibu dosen pembimbing, dosen penguji, dosen validator, kepala sekolah, dewan guru SMP Negeri 42 Pekanbaru yang sudah memberikan bimbingan dan izin untuk keterlaksanaannya peneitian ini. Serta terimakasih kepada keluarga yang sudah mendukung dalam setiap keadaan yang dialami peneliti.

\section{REFERENSI}

Akbar, S. (2013). Instrumen Perangkat Pembelajaran (1st ed.). PT. Remaja Rosdakarya.

Ariawan, R., \& Putri, K. J. (2020). Pengembangan Perangkat Pembelajaran Matematika dengan Model Pembelajaran Problem Based Learning disertai Pendekatan Visual Thinking pada Pokok Bahasan Kubus dan Balok Kelas VIII. Juring (Journal for Research in Mathematics Learning), 3(3).

Efrida, E., Halaman, M., \& Muchlis, E. E. (2012). Pengaruh Pendekatan Pendidikan Matematika Realistik Indonesia (PMRI) Terhadap Perkembangan Kemampuan Pemecahan Masalah Siswa Kelas II SD Kartika 1.10 Padang. Jurnal Exacta, 2.

Hadi, S. (2017). Pendidikan Matematika Realistik: Teori, Pengembangan, dan Implementasinya (1st ed.). PT. Rajawali Pers.

Indira, T., Zulkardi, Z., \& Sanova, Y. (2019). Peningkatan Kemampuan Pemecahan Masalah pada Materi Persamaan Garis Singgung Lingkaran melalui Pembelajaran Discovery Learning. Edumatika: Jurnal Riset Pendidikan Matematika, 2(2). https://doi.org/10.32939/ejrpm.v2i2.343

Khomsiatun, S., \& Retnawati, H. (2015). Pengembangan Perangkat Pembelajaran Dengan Penemuan Terbimbing Untuk Meningkatkan Kemampuan Pemecahan Masalah. Jurnal Riset Pendidikan Matematika, 2(1). https://doi.org/10.21831/jrpm.v2i1.7153

Mulyatiningsih, E. (2012). Metode Penelitian Terapan Bidang Pendidikan (1st ed.).

Nazarudin. (2007). Manajemen Pembelajaran: Implementasi Konsep, Karakteristik dan Metodologi Pendidikan Agama Islam di Sekolah Umum (1st ed.). Teras.

Pribadi, B. A. (2009). Model Desain Sistem Pembelajaran (1st ed.). Dian Rakyat.

Sinambela, P. N. J. M. (2017). Kurikulum 2013 dan Implementasinya dalam Pembelajaran. E-Journal Universitas Negeri Medan, 6(2).

Sudijono, A. (2009). Pengantar Statistik Pendidikan. PT. Raja Grafindo Persada.

Sunarto \& Agung Hartono. (2013). Perkembangan Peserta Didik (5th ed.). Rineka Cipta.

Trianto. (2009). Mendesain Model Pembelajaran Inovatif-Progresif: Konsep, Landasan, dan Implementasinya pada Kurikulum Tingkat Satuan Pendidikan (KTSP). Kencana Prenada Media Grup. 
Pengembangan Perangkat Pembelajaran Menggunakan Model Discovery Learning Berbasis Pembelajaran Matematika Realistik pada Materi Garis Singgung Lingkaran Kelas VIII SMP/MTs, Parsaoran Selpanri Sitorus, Nahor Murani Hutapea, Rini Dian Anggraini

Wijaya, A. (2012). Pendidikan Matematika Realistik: Suaitu Alternatif Pendekatan Pembelajaran Matematika Realistik (1st ed.). Graha Ilmu.

Yuliana, R. (2017). Pengembangan Perangkat Pembelajaran dengan Pendekatan PMRI pada Materi Bangun Ruang Sisi Lengkung untuk SMP Kelas IX. Jurnal Pendidikan Matematika, 6, 60-67.

Yustianingsih, R., Syarifuddin, H., \& Yerizon, Y. (2017). Pengembangan Perangkat Pembelajaran Matematika Berbasis Problem Based Learning (PBL) untuk Meningkatkan Kemampuan Pemecahan Masalah Peserta Didik Kelas VIII. JNPM (Jurnal Nasional Pendidikan Matematika), 1(2). https://doi.org/10.33603/jnpm.v1i2.563 